\title{
Induction versus noninduction antiviral therapy for chronic hepatitis $C$ virus in patients with congenital coagulation disorders: A Canadian multicentre trial
}

\author{
A Chatterjee $M D^{1}, M G$ Swain $M D^{2}$, SS Lee $M D^{2}$, VG Bain $M D^{3}, K$ Peltekian $M D^{4}$, \\ K Croitoru $M D^{5}, P C$ Adams $M D^{6}, K$ Kaita $M D^{7}$, J Teitel $M D^{1}$, EJ Heathcote $M D^{1}$
}

\begin{abstract}
A Chatterjee, MG Swain, SS Lee, et al. Induction versus noninduction antiviral therapy for chronic hepatitis $\mathrm{C}$ virus in patients with congenital coagulation disorders: A Canadian multicentre trial. Can J Gastroenterol 2007;21(2):91-95.
\end{abstract}

BACKGROUND: Patients with congenital coagulation disorders and chronic hepatitis $\mathrm{C}$ virus (HCV) infection have multiple risk factors (ie, infection predominantly with genotype-1 HCV, long duration of the disease, HIV coinfection and male sex) for poor response to antiviral therapy. The present study compared induction therapy with interferon-alpha (IFN- $\alpha)$-2b with standard IFN- $\alpha 2 b$ therapy. Pegylated IFN was not available at the time that the study was initiated.

PATIENTS AND METHODS: A randomized study was performed comparing the efficacy of traditional IFN- $\alpha 2 b$ therapy (group A three million units, three times weekly for 24 to 48 weeks) and daily ribavirin ( $1.0 \mathrm{~g}$ to $1.2 \mathrm{~g}$ according to weight for 24 to 48 weeks), with induction IFN- $\alpha 2$ b therapy (group B - three million units, daily for eight weeks followed by the same dose administered three times a week for a further 16 to 40 weeks) and daily ribavirin (same dose as above) in IFN-naive patients with congenital coagulation disorders and chronic HCV infection.

RESULTS: Between 2000 and 2003, 54 HIV-negative patients were recruited and randomly assigned to group $A$ or $B(n=27$ each). Both groups were comparable in terms of age, sex, ethnicity, body mass index, baseline HCV RNA titre, viral genotype, liver fibrosis stage and type of coagulation disorder. Induction therapy did not significantly alter sustained virological response rates (group A 50\%, group B 50\%; $\mathrm{P}=1.0$ ). Multiple logistic regression analysis indicated that induction therapy did not benefit individuals with difficult-to-treat infection (ie, those infected with genotypes 1 and 4 , or those with high baseline viral loads).

CONCLUSIONS: There was no benefit with induction antiviral therapy for HCV infection in individuals with congenital coagulation disorders.

Key Words: Chronic hepatitis C; Hemophilia; Induction dosing; Interferon; Repairing
Traitement antiviral inducteur vs non inducteur de l'hépatite $\mathrm{C}$ chronique chez des patients atteints de troubles héréditaires de la coagulation : Étude canadienne multicentrique

HISTORIQUE : Les patients atteints de troubles héréditaires de la coagulation qui présentent une hépatite $\mathrm{C}$ chronique sont exposés à plusieurs facteurs de risque (p. ex., infection causée surtout par le génotype 1 du $\mathrm{HCV}$, maladie de longue date, co-infection par le VIH et sexe masculin) qui les prédisposent à répondre plus ou moins bien au traitement antiviral. La présente étude comparait le traitement d'induction au traitement standard par interféron alpha (IFN- $\alpha$ )-2b. L'IFN PEGylé n'était pas disponible à l'époque où l'étude a débuté.

PATIENTS ET MÉTHODES : Une étude randomisée a été réalisée pour comparer l'efficacité du traitement standard par IFN- $\alpha 2 \mathrm{~b}$ (groupe A - trois millions d'unités, trois fois par semaine pendant 24 à 48 semaines) et ribavirine administrée quotidiennement (à raison de $1,0 \mathrm{~g}$ à $1,2 \mathrm{~g}$ selon le poids pendant 24 à 48 semaines), à celle d'un traitement d'induction par IFN- $\alpha 2$ b (groupe B - trois millions d'unités quotidiennement pendant huit semaines, puis trois fois par semaine pendant les 16 à 40 semaines suivantes) et ribavirine (à la même posologie que précédemment), chez des patients atteints de troubles héréditaires de la coagulation et d'une hépatite $\mathrm{C}$ chronique n'ayant encore jamais été exposés à l'IFN.

RÉSULTATS : Entre 2000 et 2003, 54 patients VIH-négatifs ont été recrutés et assignés aléatoirement au groupe $\mathrm{A}$ ou au groupe $\mathrm{B}(\mathrm{n}=27$ chacun). Les deux groupes étaient comparables sur le plan de l'âge, du sexe, de la race, de l'indice de masse corporelle, du titre d'ARN du HCV au départ, du génotype viral, du stade de fibrose hépatique et du type de coagulopathie. Le traitement d'induction n'a pas significativement modifié le taux de réponse virologique soutenue (groupe A : $50 \%$; groupe B : $50 \% ; \mathrm{p}=1,0)$. L'analyse de régression logistique multiple a révélé que le traitement d'induction n'offrait aucun avantage aux individus atteints d'une infection rebelle (c.-à-d., infectés par les génotypes 1 et 4 , ou dont la charge virale au départ était élevée).

CONCLUSION : Le traitement antiviral d'induction n'a semblé conférer aucun avantage particulier aux personnes atteintes de troubles héréditaires de la coagulation et d'une hépatite $\mathrm{C}$.
$\mathrm{T}$ he majority of patients with congenital coagulation disorders (ie, hemophilia A or B, or von Willebrand's disease), who received plasma-derived coagulation products before 1990, became infected with hepatitis C virus (HCV). Chronic $\mathrm{HCV}$ infection is recognized as a major cause of morbidity and mortality in these patients, primarily due to chronic hepatitis and hepatocellular carcinoma (1). Furthermore, because individuals with congenital coagulation disorders were exposed to thousands of donors, they were at high risk of also becoming coinfected with HIV, which exacerbates both morbidity and mortality (2). Because the risk of bleeding is lifelong, most individuals have been infected since childhood; thus, the long duration of infection with or without coinfection puts these individuals at risk of more severe liver diseases (3).

Department of Medicine, ${ }^{1}$ University of Toronto, Toronto, Ontario; ${ }^{2}$ University of Calgary, Calgary; ${ }^{3}$ University of Alberta, Edmonton, Alberta;

${ }^{4}$ Dalhousie University, Halifax, Nova Scotia; ${ }^{5}$ McMaster University, Hamilton; ${ }^{6}$ University of Western Ontario, London, Ontario;

${ }^{7}$ University of Manitoba, Winnipeg, Manitoba

Correspondence: Dr EJ Heathcote, Toronto Western Hospital, Fell Pavilion, Floor 6B - Room 156, University Health Network, 399 Bathurst Street,

Toronto, Ontario M5T 2S8. Telephone 416-603-5914, fax 416-603-6281, e-mail jenny.heathcote@utoronto.ca

Received for publication March 9, 2006. Accepted May 2, 2006 
Although the prevalence of HCV infection is high in patients with congenital coagulopathies, such patients were never included in industry-funded phase III trials, perhaps because of a perceived high risk of liver biopsy in this patient population. Additionally, because HCV was never their primary medical condition and because chronic HCV is usually clinically silent, the need for antiviral treatment was easy to overlook, particularly if coinfection with HIV was present; the latter disease taking precedence in terms of need for therapy. By virtue of the inheritance of hemophilia, the majority of this population is male. Male predominance and the longevity of infection are two characteristics associated with poor response to interferon-alpha (IFN- $\alpha$ ) treatment and more severe liver disease. Potentially, more potent treatment strategies may be required for this unique population (4).

In the present study, we present the results of a prospective randomized, multicentre trial evaluating the efficacy of an induction dose of IFN- $\alpha 2 b$ together with ribavirin in comparison with noninductive combined therapy for the treatment of chronic HCV infection in patients with congenital coagulation disorders. Pegylated (PEG) IFN- $\alpha$ was not licensed in Canada at the time that the present study was initiated.

\section{Study population}

\section{PATIENTS AND METHODS}

Patients were recruited from university-affiliated hospitals across Canada from the University of Toronto (Toronto, Ontario), University of Western Ontario (London, Ontario), McMaster University (Hamilton, Ontario), Dalhousie University (Halifax, Nova Scotia), University of Calgary (Calgary, Alberta), University of Alberta (Edmonton, Alberta) and the University of Manitoba (Winnipeg, Manitoba). Patients in the present study were under the joint care of a hematologist and a hepatologist. The study was approved by the local research ethics board at each institution, and written informed consent was obtained from each patient before entry.

\section{Eligible patients}

Eligible patients had to be between 18 and 65 years of age with a documented congenital coagulation disorder. Patients were required to have been followed for six months or more, test anti-HCV-positive, have detectable HCV RNA, and have serum aminotransferase levels above normal at some time during the previous six-month period, with or without a liver biopsy that showed chronic HCV. IFN-naive patients were eligible as were those who had relapsed following IFN therapy in the past, defined as individuals who had normal serum aminotransferase levels at the end of a course of IFN- $\alpha$ but whose liver enzymes subsequently became abnormal again once treatment was stopped and had detectable HCV RNA in the serum at the time of the study. Other inclusion criteria included hemoglobin $(\mathrm{Hb})$ levels of $120 \mathrm{~g} / \mathrm{L}$ or greater, white blood cell counts greater than $3.0 \times 10^{9} / \mathrm{L}$, with absolute neutrophil counts of $1500 / \mathrm{mm}^{3}$ or greater, platelet counts greater than $70 \times 10^{9} / \mathrm{L}$, normal serum creatinine levels of $110 \mu \mathrm{mol} / \mathrm{L}$ or less, serum bilirubin levels within the normal range (unless known to have Gilbert's syndrome), no evidence of current hepatitis B infection (hepatitis B surface antigennegative), normal thyroid-stimulating hormone levels, HbA1c levels of $8.5 \%$ or less in diabetic patients, no signs of hepatocellular carcinoma on abdominal ultrasound, acceptable contraceptive practices and voluntary informed consent.
Patients were excluded if they had not met the inclusion criteria; had evidence of decompensated liver disease, a history of cardiovascular dysfunction, a pre-existing or current severe psychiatric disorder, uncontrolled seizures, clinical gout, factor VIII inhibitor that could not be 'overcome'; were pregnant or intended to impregnate their partner during the treatment or follow-up period; or had concurrent immunosuppressive therapy, autoimmune disease, uncontrolled diabetes, other causes of liver disease (ie, Wilson disease or alcoholic liver disease), hemoglobinopathy or a $\mathrm{CD}_{4}$ count less than 200 if HIV-positive.

\section{Randomization/sample size}

Randomization was performed by the central study coordinator based in Toronto, Ontario. Block randomization (block size of four) was used to stratify by centre and HIV status. The pharmacy at each of the centres dispensed all needed medications.

\section{Power}

The initial study design included a cohort of hemophilics who also contracted HIV. Estimates based on the review of clinical records of hemophilics in Toronto, Ontario, with both HIV and HCV, suggested that the seven Canadian centres would potentially be able to recruit 38 patients with this coinfection. It was estimated that 60 patients would need to be recruited into each of the two treatment arms of the study, for a total of 120 patients. Unfortunately, enrollment of the HIV-positive cohort was poor and therefore not included in the final analysis. Power calculations were based on the following two hypotheses: combined therapy of HCV infection with IFN- $\alpha 2 b$ and ribavirin is effective in patients with congenital coagulation factor abnormalities (power 88\%), and combination therapy which includes an induction phase is more effective than standard combination therapy in achieving a sustained virological response (SVR) (power 78\%). SVR is defined as having sustained loss of HCV RNA six months postcessation of therapy.

\section{Treatment}

Ribavirin was dosed according to weight $-1000 \mathrm{mg} /$ day if the patient weighed $75 \mathrm{~kg}$ or less, or $1200 \mathrm{mg} / \mathrm{day}$ if the patient weighed more than $75 \mathrm{~kg}$. The first injection of IFN- $\alpha 2 \mathrm{~b}$ (Intron A, Schering Canada Inc) was administered in a monitored clinical setting with access to antianaphylactic therapy due to the risk of acute hypersensitivity reactions. Standard therapy consisted of an IFN- $\alpha 2 b$ dose of three million units (MU), three times weekly for 24 to 48 weeks. Induction therapy consisted of an IFN- $\alpha 2 b$ dose of $3 \mathrm{MU}$ daily for eight weeks followed by doses of $3 \mathrm{MU}$ administered three times a week for 16 to 40 weeks. The duration of therapy was 24 weeks for all patients with genotypes 2 and 3 , and 48 weeks for those with genotypes 1 and 4 . For the latter group of patients, if their HCV RNA remained detectable at 24 weeks into therapy, treatment was terminated.

\section{Patient evaluation}

Eligible patients underwent a complete physical examination at screening or week 0 , at the end of treatment (ETR) and at the end of the follow-up period. Screening tests were performed according to the inclusion criteria. Transjugular liver biopsy was recommended within one year of starting treatment. HCV RNA was measured at a central laboratory in Toronto, Ontario, and the genotyping was performed in the provincial laboratory using the Roche Cobas Amplicor and Innogenetics' immunoblotting assays (Roche Diagnostics, Belgium). 
TABLE 1

Patient demographics ( $n=27$ for both groups $A$ and $B$ )

\begin{tabular}{|c|c|c|c|}
\hline Factor & $\begin{array}{c}\text { Group A } \\
\text { (traditional IFN therapy) }\end{array}$ & $\begin{array}{c}\text { Group B } \\
\text { (induction IFN therapy) }\end{array}$ & $\mathbf{P}$ \\
\hline $\begin{array}{l}\text { Baseline HCV RNA, } \times 10^{4} \mathrm{IU} / \mathrm{mL} \\
(\text { mean } \pm \mathrm{SD})^{*}\end{array}$ & $13.19 \pm 1.55$ & $14.01 \pm 1.72$ & 0.64 \\
\hline \multicolumn{4}{|l|}{ Sex, n (\%) } \\
\hline Men & $23(85.19)$ & $22(81.48)$ & 1.00 \\
\hline Caucasian & $24(88.89)$ & 25 (92.59) & 0.98 \\
\hline Other & $3(11.11)$ & $2(7.41)$ & \\
\hline \multicolumn{4}{|l|}{ Genotype, n (\%) } \\
\hline 1 and 4 & $16(59.26)$ & $19(70.37)$ & 0.39 \\
\hline 2 and 3 & $11(40.74)$ & $8(29.63)$ & \\
\hline \multicolumn{4}{|l|}{ Coagulation disorder, $\mathrm{n}(\%)$} \\
\hline Hemophilia A & $18(66.67)$ & $16(59.26)$ & 0.79 \\
\hline Hemophilia B & $5(18.52)$ & $4(14.81)$ & \\
\hline Hypofibrinogenemia & $0(0)$ & $1(3.70)$ & \\
\hline von Willebrand's disease & $4(14.81)$ & $6(22.22)$ & \\
\hline Body mass index $\ddagger$ & $27.6(n=20)$ & $27.4(n=21)$ & 1.00 \\
\hline
\end{tabular}

${ }^{*}$ Natural logarithm of hepatitis C virus (HCV) RNA was used and Student's t test was used on the transformed scores; 'TSeven patients in group $A$ and five patients in group $B$ were refused liver biopsy, ${ }^{\ddagger}$ Not available for all patients. IFN Interferon

While on treatment, enrolled patients were followed up at weeks $1,2,4,8,12,16,20,24,30,36,42$ and 48, and at weeks 12 and 24 post-treatment. During each visit, patients were evaluated for medication history, treatment side effects, drug compliance and efficacy of therapy; blood tests were also performed. Data were collected upon entry to the study and at follow-up visits, on standardized data collection forms, and subsequently coded to a computerized database.

\section{Adverse events}

The side effects recorded at follow-up visits included fatigue, headache, depression, myalgia, impaired concentration, and a fall in $\mathrm{Hb}$ levels with or without a concomitant rise in bilirubin levels and reticulocyte counts. Management of adverse reactions was achieved by predetermined dose reduction guidelines based on the modified World Health Organization toxicity grading scale for determining the severity of adverse events (5). IFN- $\alpha 2 \mathrm{~b}$ doses were reduced by $50 \%$ if the patient developed white blood cell counts of less than $1.5 \times 10^{9} / \mathrm{L}$, granulocyte counts of less than $0.75 \times 10^{9} / \mathrm{L}$, platelet counts of less than $50 \times 10^{9} / \mathrm{L}$, severe symptoms of depression, 'flulike symptoms and lethargy. Ribavirin doses were reduced by $50 \%$ if $\mathrm{Hb}$ levels were less than $100 \mathrm{~g} / \mathrm{L}$, or dropped by $20 \mathrm{~g} / \mathrm{L}$ or more over a four-week period in a patient at increased cardiac risk. After resolution of an adverse event, treatment could be restarted at $50 \%$ and if this dose was tolerated for more than two weeks, the regimen was restarted at the original dose. The study drug was discontinued if the patient's adverse event did not resolve, worsened or he/she experienced recurrence. The study drug was also discontinued in cases of life-threatening adverse events, or with identification of cardiac dysfunction or pregnancy.
Statistical analysis

After patients had been randomly assigned, those who had one or more blood tests were included in an intention-to-treat analysis with the primary outcome measure being SVR. $\chi^{2}$ test and Fisher's exact analysis were used to compare the response to treatment in groups randomly assigned to 'standard' therapy and daily 'induction' therapy.

\section{Patient numbers and power}

The study was a randomized, controlled trial involving seven centres across Canada. Between February 2001 and February 2003, 61 individuals from the seven centres who had congenital coagulopathy and liver disease due to HCV were enrolled in the study. Six of 61 patients had both HCV and HIV infection and were not included in the analysis.

\section{Patient characteristics}

Treatment groups A (traditional IFN therapy, $n=27$ ) and B (induction IFN therapy, $\mathrm{n}=27$ ) were compared with respect to baseline measurements and demographic characteristics. The demographic details of these two patient populations are summarized in Table 1 . There were no significant differences between the two groups.

Of the $55 \mathrm{HCV}$ monoinfected patients who were randomly assigned, one patient never started the study medication and was not included in the statistical analysis. Four $(7.4 \%)$ patients discontinued study treatment due to adverse events at week 3, one patient had an $\mathrm{Hb}$ drop of $50 \mathrm{~g} / \mathrm{L}$, another at week 12 developed an upper respiratory tract infection, the 
third at 16 weeks became angry and depressed, and the fourth at seven months began having severe nightmares thought to be related to the treatment. In all four patients, the side effects resolved shortly after the study drug was discontinued.

The ETR viral response (undetectable HCV RNA) between the two groups was similar (group A 59\%, group B 52\%; $\mathrm{P}=0.69)$. The ETR values for three patients were unavailable and were assumed to be positive for the analysis, and the overall SVR rates were also similar between the two groups (group A 50\%, group B 50\%; P=1.0). Pretreatment viral titres, defined as low (less than $800,000 / \mathrm{U}$ ) and high $(800,000 / \mathrm{U}$ or greater), did not correlate with the ETR $(\mathrm{P}=0.84)$. Genotypes 2 and 3 (SVR 84\%) were more likely to achieve an SVR than genotypes 1 and 4 (SVR 17\%), with an OR of 29.41 (95\% CI 5.92 to 142.86). The SVR within the genotype subgroups was not influenced by treatment regimen. Eight patients with ETR relapsed during follow-up. Six of eight patients who relapsed were infected with genotype 1 .

\section{DISCUSSION}

The efficacy of IFN monotherapy for the treatment of chronic HCV is markedly enhanced by the addition of ribavirin, primarily through the prevention of relapse, demonstrated in three pivotal phase III trials (6-8). Lam et al (9) demonstrated a rebound rise in HCV RNA levels within $24 \mathrm{~h}$ to $48 \mathrm{~h}$ following a single dose of IFN, which suggests that there may be potential benefits with inductive therapy. A pilot study by Brouwer et al (10) in 1998 showed that doubling the initial IFN dosage resulted in increased early response rates in nonhemophilics. A recent large $(n=614)$ Spanish study (11) demonstrated that although the initial virological response to induction therapy ( $5 \mathrm{MU}$ daily for four weeks) was enhanced (49.6\% with induction versus $34.5 \%$ with standard treatment; $\mathrm{P}=0.0002)$, it was not maintained; in other words, the ETRs were similar $(69 \%$ versus $65 \%)$ as were the SVR rates $(50.6 \%$ versus $47.4 \%)$. The ETR values were slightly higher in the Spanish study than that observed in our study (59\% versus 52\%); however, the SVR rates were identical (both 50\%). Two other publications $(12,13)$ that reported specifically on hemophilics showed SVR rates similar to ours, and their rates were comparable with those of studies in nonhemophilic patient populations. In a study by Santagostino et al (14), inductive therapy in hemophilic patients was suggested to be more effective than standard treatment. The study demonstrated an overall SVR rate of $41 \%$, but unfortunately no control group was used in their study, whereas our study showed no difference in the SVR between traditional and inductive therapy. In 2002, a small Swedish study (15) compared six with 12 months of HCV therapy and found no significant impact on SVR rates. In 2004, the CHARIBDIS study group (16) suggested a favourable effect of induction in decreasing relapse rates in their study of induction therapy in hemophilics; however, they too were subject to poor recruitment and the overall results were not significant. Interestingly, Fried et al (17) showed significantly improved response rates in adolescents treated with standard combination therapy compared with adults, suggesting that this subpopulation may be better suited for induction therapy. Unfortunately, we did not have any adolescents in our study and our results showed no benefit of induction therapy in adults with chronic HCV without HIV coinfection. The new standard of therapy is PEG IFN and ribavirin, which in combination show enhanced efficacy likely due to the sustained IFN levels. The Dynamically Individualized Treatment of HCV (DITTO-HCV) trial in nonhemophilics used PEG IFN- $\alpha 2$ a plus ribavirin in increasing doses, and the SVR rates achieved did not differ despite the dose difference (18).

One of the main risk factors for nonresponse is genotype. In our study, the SVR rate in patients infected with genotypes 1 and 4 was only $17 \%$ compared with $84 \%$ in those infected with genotypes 2 and 3 . In our study, six of eight patients who relapsed were infected with HCV genotype 1. Patients infected with genotypes 2 and 3 appeared to be more responsive to IFN and ribavirin treatment, and the known risk factor for relapse - ie, high HCV viral load - may not have a significant influence on outcome because of enhanced IFN sensitivity.

Our study did not reveal any significant difference in response to treatment between those with high or low viral titre as defined by levels of greater or less than $800,000 / \mathrm{U}$. The majority of our patients were male (more than $80 \%$ ); therefore, we could not study the impact of sex. Bridging fibrosis (Metavir score greater than 2) has been reported as an important independent predictor of poor response (19). We found that five of eight patients who relapsed following an ETR had evidence of bridging fibrosis on liver biopsy. Although we report no significant association with these risk factors for nonresponse, we do acknowledge that the effect of these may have been lost in our analysis due to the small sample size.

The early response to treatment should be considered an important parameter in deciding the duration of treatment. Dalgard et al (20) demonstrated in a noncontrolled, multicentre trial that patients who had an early virological response at four weeks into treatment of HCV (genotypes 2 and 3) were more likely to develop an SVR. Another study by Drusano and Preston (21) suggested that prolonged viral undetectability up to at least 36 weeks may be required to obtain SVR rates of $90 \%$ for HCV genotype 1 . We found that none of our patients with detectable HCV at 24 weeks responded to an optional additional 24 weeks of treatment.

In our study, we found that there was no difference between patients treated with induction doses of IFN versus those treated with the standard intermittent therapy, both in combination with ribavirin. However, the SVR rates that were achieved were similar to those reported in studies of nonhemophilic patients, demonstrating that despite the presence of several factors for poor response, such as high Metavir score or male sex, this population can achieve SVR rates similar to those reached in $\mathrm{HCV}$-infected patients without coagulation disorders. Our data and recent reports in the literature suggest that there is no role for induction therapy in IFN-naive patients. Future studies should focus on early virological response and factors that may influence this early response phase because they appear to be important determinants in achieving SVR.

FINANCIAL SUPPORT: The project was funded by a Medical Research Council grant \#PA - 14952 with Schering Canada Inc as the industrial partner. The authors have no competing financial interests. 


\section{REFERENCES}

1. Darby SC, Ewart DW, Giangrande PL, et al. Mortality from liver cancer and liver disease in haemophilic men and boys in UK given blood products contaminated with hepatitis C. UK Haemophilia Centre Directors' Organisation. Lancet 1997;350:1425-31.

2. Lichterfeld M, Schmeisser N, Qurishi N, et al. Clinical outcomes of HIV-HCV co-infection in a large cohort of hemophiliac patients. J Infect 2005;50:221-8.

3. Poynard T, Bedossa P, Opolon P. Natural history of liver fibrosis progression in patients with chronic hepatitis C. The OBSVIRC, METAVIR, CLINIVIRC, and DOSVIRC groups. Lancet 1997;349:825-32.

4. Dughera L, Battaglia E, Serra AM, et al. Human leukocyte interferon-alpha treatment for chronic HCV-related hepatitis in hemophilic patients previously intolerant to other interferons-alpha. Dig Dis Sci 2002;47:427-31.

5. Brundage MD, Pater JL, Zee B. Assessing the reliability of two toxicity scales: Implications for interpreting toxicity data. J Natl Cancer Inst 1993;85:1138-48.

6. Poynard T, Marcellin P, Lee SS, et al. Randomised trial of interferon alpha2b plus ribavirin for 48 weeks or for 24 weeks versus interferon alpha2b plus placebo for 48 weeks for treatment of chronic infection with hepatitis $\mathrm{C}$ virus. International Hepatitis Interventional Therapy Group (IHIT). Lancet 1998;352:1426-32.

7. McHutchison JG, Gordon SC, Schiff ER, et al. Interferon alfa-2b alone or in combination with ribavirin as initial treatment for chronic hepatitis C. Hepatitis Interventional Therapy Group. N Engl J Med 1998;339:1485-92.

8. Davis GL, Esteban-Mur R, Rustgi V, et al. Interferon alfa-2b alone or in combination with ribavirin for the treatment of chronic hepatitis C. International Hepatitis Interventional Therapy Group. N Engl J Med 1998;339:1493-9.

9. Lam NP, Neumann AU, Gretch DR, Wiley TE, Perelson AS, Layden TJ. Dose-dependent acute clearance of hepatitis C genotype 1 virus with interferon alfa. Hepatology 1997;26:226-31.

10. Brouwer JT, Nevens F, Kleter, B et al. Efficacy of interferon dose and prediction of response in chronic hepatitis C: Benelux study in 336 patients. J Hepatol 1998;28:951-9.

11. Perez R, Jimenez M, Crespo J, et al. Comparative study of the efficacy of an induction dose of interferon-alpha2b with ribavirin compared with standard combined treatment in naive patients with chronic hepatitis C. J Viral Hepat 2003;10:437-45.
12. Sauleda S, Esteban JI, Altisent C, Puig L, Esteban R, Guardia J. Treatment with interferon plus ribavirin in anti-HIV negative patients with congenital coagulation disorders and chronic hepatitis C Thromb Haemost 2000;83:807-10.

13. Shields PL, Mutimer DJ, Muir D, et al. Combined alpha interferon and ribavirin for the treatment of hepatitis $\mathrm{C}$ in patients with hereditary bleeding disorders. Br J Haematol 2000;108:254-8.

14. Santagostino E, De Filippi F, Rumi MG, Rivi M, Colombo M, Mannucci PM; Hepatitis Study Group of the Association of Italian Hemophilia Centers. Sustained suppression of hepatitis $C$ virus by high doses of interferon and ribavirin in adult hemophilic patients. Transfusion 2004;44:790-4.

15. Schulman S, Kinnman N, Lindmarker P, von Sydow M. A randomized study of alpha-interferon plus ribavirin for 6 months or 12 months for the treatment of chronic hepatitis $\mathrm{C}$ in patients with bleeding disorders. Haemophilia 2002;8:129-35.

16. Meijer K, Haagsma EB, van der Meer J; CHARIBDIS Study Group. A randomized, double-blind, placebo-controlled clinical trial of high-dose interferon-alpha induction treatment combined with ribavirin for chronic hepatitis $\mathrm{C}$ in hemophilia. J Thromb Haemost 2004;2:194-6.

17. Fried MW, Peter J, Hoots K, et al. Hepatitis C in adults and adolescents with hemophilia: A randomized, controlled trial of interferon alfa-2b and ribavirin. Hepatology 2002;36:967-72.

18. Zeuzem S, Powlotsky JM, Lukasiewicz E, et al; DITTO-HCV Study Group. International, multicenter, randomized, controlled study comparing dynamically individualized versus standard treatment in patients with chronic hepatitis C. J Hepatol 2005;43:250-7.

19. Karino Y, Toyota J, Sugawara M, et al. Hepatitis C virus genotypes and hepatic fibrosis regulate $24-\mathrm{h}$ decline of serum hepatitis $\mathrm{C}$ virus RNA during interferon therapy in patients with chronic hepatitis C. J Gastroenterol Hepatol 2003;18:404-10.

20. Dalgard O, Bjoro K, Hellum KB, et al. Treatment with pegylated interferon and ribavarin in HCV infection with genotype 2 or 3 for 14 weeks: A pilot study. Hepatology 2004;40:1260-5.

21. Drusano GL, Preston SL. A 48-week duration of therapy with pegylated interferon alpha2b plus ribavirin may be too short to maximize long-term response among patients infected with genotype-1 hepatitis C virus. J Infect Dis 2004;189:964-70. 


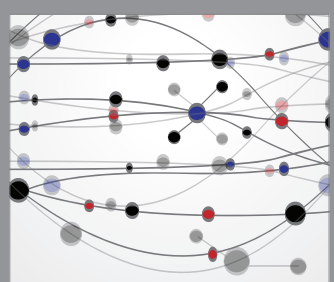

The Scientific World Journal
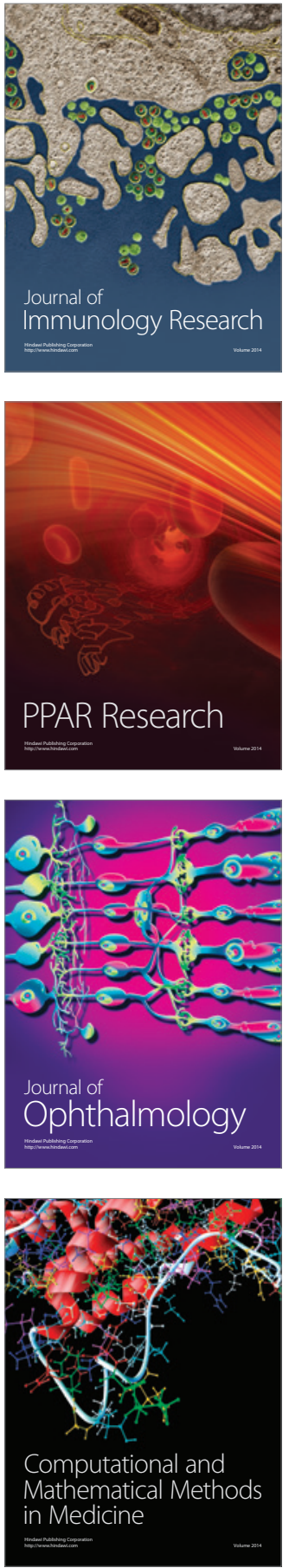

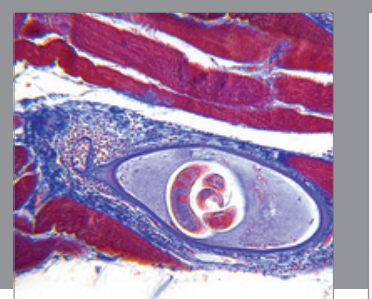

Gastroenterology Research and Practice

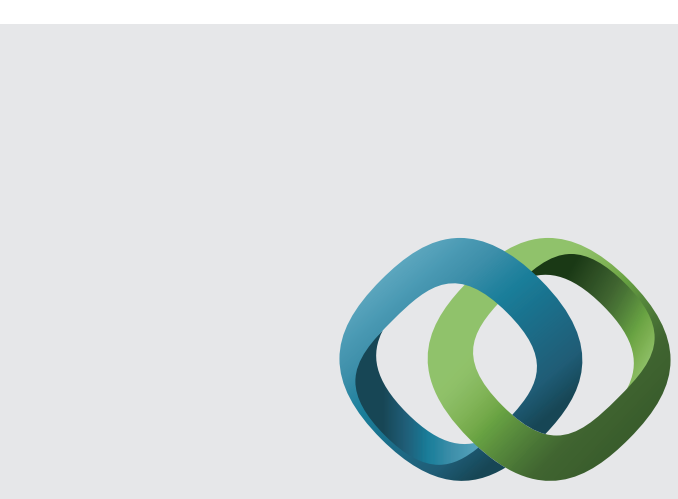

\section{Hindawi}

Submit your manuscripts at

http://www.hindawi.com
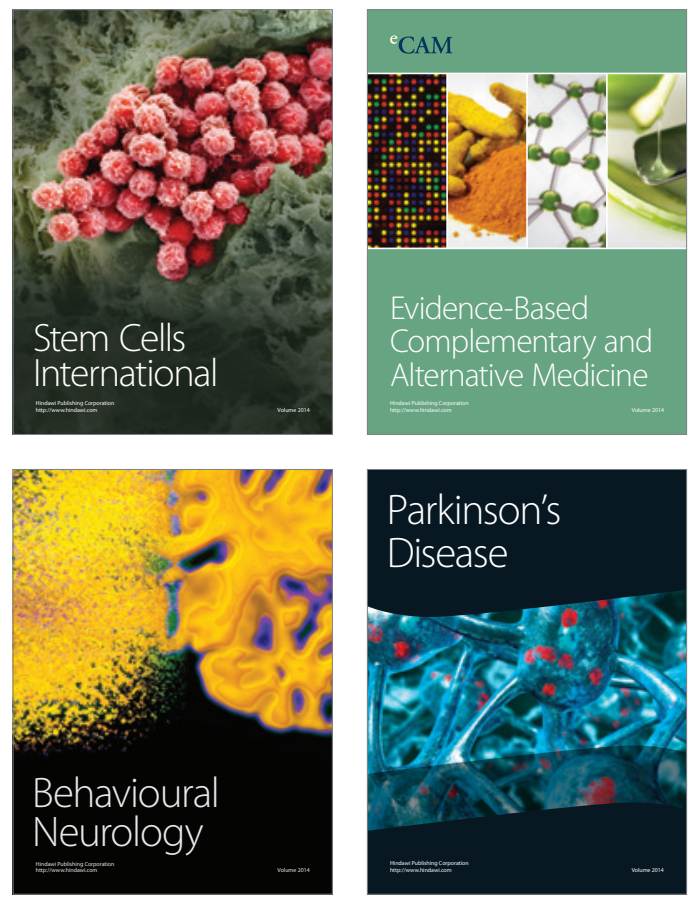
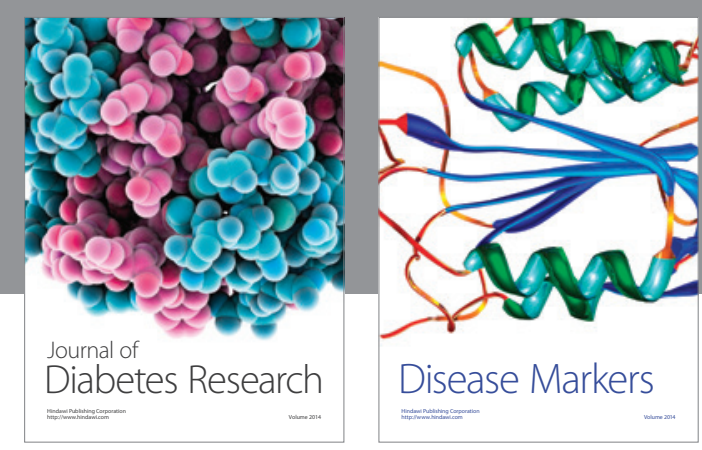

Disease Markers
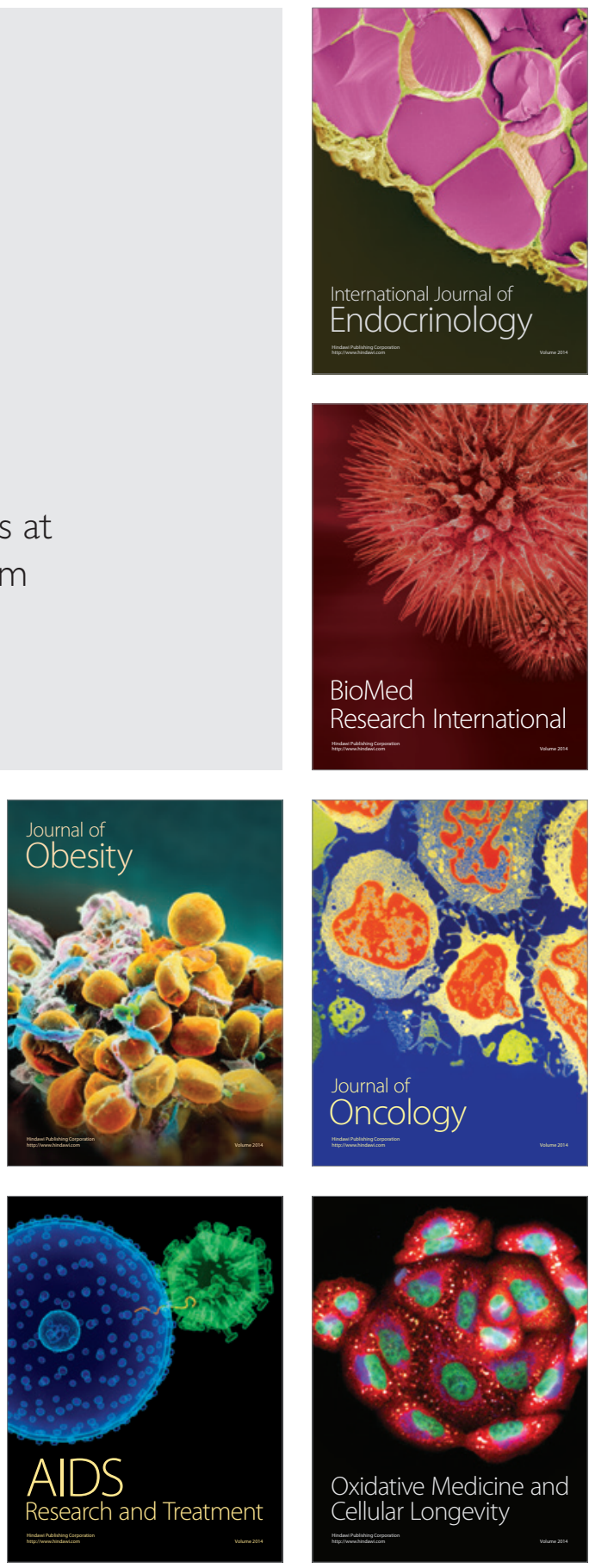